\title{
NATURAL COMPOUNDS: A SUSTAINABLE ALTERNATIVE TO THE PHYTOPATHOGENS CONTROL
}

\author{
MARÍA FERNANDA JIMÉNEZ-REYES ${ }^{A}$, HÉCTOR CARRASCO ${ }^{B}$, ANDRÉS F. OLEA ${ }^{B}$, EVELYN SILVA-MORENO ${ }^{4, C^{*}}$ \\ ${ }^{a}$ Instituto de Ciencias Biomédicas, Universidad Autónoma de Chile, Chile \\ ${ }^{b}$ Instituto de Ciencias Químicas Aplicadas, Facultad de Ingeniería, Universidad Autónoma de Chile, Chile. \\ ${ }^{c}$ Instituto de Investigaciones Agropecuarias, INIA-La Platina, Santiago, Chile
}

\begin{abstract}
Fungi are the primary infectious agents in plants causing significant economic losses in agroindustry. Traditionally, these pathogens have been treated with different synthetic fungicides such as hydroxianilides, anilinopyrimidines, and azoles, to name a few. However, the indiscriminate use of these chemicals has increased fungi resistance in plants. Natural products have been researched as a control, and an alternative to these synthetic fungicides since they are not harmful to health and contribute to the environment caring. This review describes plants extracts, essential oils, and active compounds or secondary metabolites as antifungal agents both, in vitro and in vivo. Active compounds have been recently described as the best candidates for the control of phytopathogenic fungi. When metabolized by plants, these compounds concentrations rely on the environmental conditions and pathogens incidence. However, one issue regarding the direct application of these preformed compounds in plants touch upon their low persistence in the environment, and their even lower bioavailability than synthetic fungicides. Hence the challenge is to develop useful formulations based on natural products to increase the compounds solubility facilitating thus their application in the field while maintaining their properties.
\end{abstract}

Keywords: fungus; phytopathogen; antifungal; natural control; plant extract; essential oil; secondary metabolite

\section{INTRODUCTION}

Agriculture holds a direct influence on the world economy, primarily due to the fruits, grains, and vegetable production, which represent an essential source of economic income both nationally and internationally $[1,2]$. However, plants exposed to environmental conditions are prone to be threatened by a variety of pathogenic microorganisms such as bacteria, viruses, nematodes, and fungi. These pathogens cause significant crop yield loss $[3,4,5,6]$.

Phytopathogenic fungi are one of the leading infectious agents in plants causing alterations during the different plant-stages growth, post-harvest and even during storage. There is a wide variety of fungal genus currently generating quality problems in fruits and vegetables, affecting thus their nutritional value, organoleptic characteristics and half-life $[4,7,8,9]$. More than $25 \%$ of cereals (rice, flour, maize, etc.) are contaminated in some cases by fungi belonging to the genera Aspergillus and Fusarium, indirectly responsible for producing known mycotoxins, and Aflatoxin B1 (toxic and potent carcinogen ); as well as more than 300 fungal metabolites, which can generate allergic or poisonous disorders such as carcinogenicity, genotoxicity, teratogenicity, nephrotoxicity, hepatotoxicity, reproductive disorders, and immunosuppression in consumers [7, $8,9]$.

Traditionally, infections caused by phytopathogenic fungi have been controlled using synthetic fungicides, [4]. For instance, most of these synthetic antifungals used in agriculture belong to the "azole group". These are divided into two major groups: triazoles and imidazoles. The first one has a broad spectrum of action, and its function is to inhibit sterol biosynthesis in the plasma membrane, resulting in the alteration of cell formation and structure $[7,10,11$, $12,13]$. While the second group inhibits the cell division mechanism (mitosis), by disrupting the tubulin biosynthesis and the mitotic spindle, consequently $[6$, $11,12,14]$. In this way, one of the significant advantages associated with the use of azoles is the food preservation against fungi growth and the protection of plants from fungal diseases, increasing thus the production yield [15]. However, these compounds also have disadvantages, such as: 1) Toxic waste in both, plant and fruits after treatment. Besides, its persistence in the product generates concern in the consumer, since fruits and vegetables are consumed in a relatively short time after harvest. Furthermore, the National Academy of Sciences (NAS) established that fungicide residues in foods are carcinogenic and considered to be hazardous to human health $[14,16]$. 2) The use and abuse of these compounds can generate resistance in pathogenic fungi $[17,18,19]$. 3) The danger of handling them, due to the possible intoxication and infertility triggered in people who manipulate those compounds [20]. 4) Since they are not readily biodegradable, they tend to persist several years in the environment, considering them as environmental impact products $[14,16]$. 5) They cannot be used on organic fruit produced with "green" laws and standards [14] . 6) High cost; around $20 \%$ of the production cost is spent on fungicides $[4,13,15]$.
Based on disadvantages previously described, there are restrictions currently active regarding azoles usage (synthetic fungicides), increasing thus regulation and promoting the search for new strategies. The Environmental Protection Agency (EPA) suggests, as an alternative, the natural type control, since it does not present side effects, does not harm the environment, has an extensive public acceptance, and is relatively economic $[10,13,15,21,22]$.

Therefore, the interest in researching organic and useful products likely used as a natural control, and generating thus a sustainable and profitable industry, has become increasingly important $[8,18,23,24,25]$. Some of the natural antifungals currently used are microorganisms, extracts, essential oils, or active compounds from plants $[4,19,22,26]$.

Plant extracts used as a natural control against phytopathogenic fungi: To reduce the use of chemical antifungals, the study of natural products exhibiting antifungal activity has become extremely important since plants have physiological properties or "defense mechanisms", whose functions allow them to metabolize active compounds generating protection against insects and preventing pathogens invasion [27]. Adding the fact that these metabolites are not harmful to health and contribute to the environmental care $[9,21,22]$, they are considered as an excellent alternative for the control of phytopathogenic fungi.

\section{MATERIALS AND METHOD}

\section{Plant extracts}

Plant extracts are products generated from roots, barks, seeds, shoots, leaves, and fruits, coming from some plants with medicinal tradition and other plants chosen by their defense mechanism [27]. The process usually consists on macerate the plant material with different polarity solvents, followed by the purification through chromatographic methods of the obtained extracts to obtain individual compounds, which finally leads to the metabolites isolation in pure form. It is also reported that both, the method and the solvent whereby this procedure's final substance (extract) is obtained, influences the amount and number of compounds or secondary metabolites attributed to have antifungal property. Thus, the extracts may contain different compounds or the same compounds, but in varying amounts, which influences their antifungal properties $[7,10]$.

Overall, several plant extracts have been studied to evaluate this antifungal capacity. For instance, the antifungal activity against eight species of fungi from the Aspergillus genus has been determined in vitro, (A. candidus, A. columnaris, A. flavipes, A. flavus, A. fumigatus, A. niger, A. ochraceus and A. tamari), from aqueous extracts of Acacia nilotica, Achras zapota, Datura stramonium, Emblica officinalis, Lawsonia inermis, Mimusops elengi, Peltophorum pterocarpum, Prosopis juliflora, Punica granatum, and Syzigium cumini. Similarly, aqueous extracts from A. nilotica, M. elengi, and P. juliflora plants, and have shown to 
inhibit $A$. niger mycelial growth (black mold in vegetables), suggesting that these aqueous extracts could serve as antifungal against phytopathogenic fungi from the Aspergillus genus [9].

In the same line, peel and juice extracts from pomegranate (Punica granatum), both aqueous and alcoholic, could act as a natural control of phytopathogenic fungi multispecies, since they have a high fungi activity against A. niger, Penicillium citrinum (citrus rust), and Rhizopus oryzae (pathogen infecting carrots, pineapples, and mangoes) [28]. Additionally, garlic (Allium sativum) and clove (Syzygium aromaticum) alcoholic extracts, present a maximum inhibition percentage of mycelial growth against Rhizopus stolonifer, a filamentous fungus found in fruits such as papaya (Carica papaya) [29]. On the other hand, the aqueous Zimmu leaf extract, an interspecific hybrid between garlic and onion (Allium sativum x Allium cepa), has been described to be a potent antifungal against Mycosphaerella eumusae fungus, the causal agent of Eumusae (foliar banana spot disease), as it can completely inhibit conidia mycelial growth and germination [19]. Another extract which could be considered as a natural control of Mycosphaerella eumusae (with a lower level of effectiveness) is the one from Senna (Cassia senna) and Snake Jasmine (Rhinacanthus nasutus) plants, which can only inhibit conidia germination [19].

Keeping up with antifungal extracts activity, the cinnamon extract from a southern China native plant (Cinnamomum cassia), can significantly inhibit $A$. niger growth. This extract also inhibits growth in Botrytis cinerea, Fusarium moniliforme (maize pathogen), and Phyllosticta caricae (papaya pathogen) phytopathogenic fungi [8]. Moreover, plant extracts such as wild blackberry (Rubus ulmifolius), carob tree (Ceratonia siliqua), rock rose (Cistus monspeliensis) and Halimium (Halimium umbellatum), completely inhibit mycelial growth of Geotrichum candidum fungus, which causes the rot pathogen of citrus plants in roots, both in vitro and in vivo. Whereas, H. umbellatum's and rock rose's (Cistus villosus) aqueous extracts inhibit the Geotrichum candidum spore germination, suggesting that they have a high potential to control this pathogen [2]. Besides, ethanolic extracts of clove basil (Ocimum gratissimum) and grains of paradise (Aframomum melegueta), could be useful as multispecies natural control, reducing both, spore germination and mycelial growth of $A$. flavus, A. niger, Botryodiplodia theobromae, Fusarium oxysporum, Fusarium solani, Penicillium chrysogenum, Rhizoctonia sp., Penicillium oxalicum, Trichoderma viride, and Rhizopus nodosus fungi, causal agents of yam (Dioscorea spp.), a highly cultivable product in Africa's tropical countries due to its high nutritional content [30]. Furthermore, the A. melegueta ethanolic extracts, the garlic (A. sativum) methanolic extracts, as well as the ginger (Zingiber officinale), can also inhibit $A$. niger fungus growth [31]. Indicating then, that these three extracts could work also as natural prophylaxis against fungal infections.

Jarilla macho (Zuccagnia punctata), and chaparral (Larrea divaricata) alcoholic extracts have a mycelial growth inhibitory effect against wood; destroying Lenzites elegans, Ganoderma applanatum, Pycnoporus sanguineus, and Schizophyllum commune fungi. While, the alcoholic extracts from the Peruvian peppertree (Schinus molle) inhibit F. oxysporum, A. niger, and Trichoderma spp. growth. It has also been reported that alcoholic extracts of creosote bush (Larrea cuneifolia) have activity only against $F$. oxysporum, implying that these alcoholic extracts could function as an antifungal for some phytopathogenic fungi species [32]. Aqueous extracts of Chuquiraga atacamensis, Parastrephia phyliciformis, and Parastrephia lepidophylla (extremophilic plants of the Argentine Puna), have shown antifungal activity in vitro and in vivo against Penicillium digitatum and Geotrichum citri-aurantii fungi species which cause post-harvest citrus disease. Therefore, they exert healing effects on fruits [22]. Moreover, for the fungus Penicillium expansum (fruit pathogen, e.g. apples), capsaicin extract from Capsicum spp. could be used as a preventive method, revealing the capacity in vivo to hold fungus growth back during the first 14 test days [23]. Besides, for the $P$. expansum fungus, the capsaicin extract from Capsicum spp. could be used as a preventive method, observing also the capacity in vivo to hold the fungus growth back during the first 14 test days [21].

In the same way, algae could be considered as phytopathogenic fungi with antifungal properties, as suggested by [33]. These authors reported that hexane/ethyl acetate (EtOAc) extracts from red algae (Stypopodium zonale, Laurencia dendroidea, Pelvetia canaliculata, Sargassum muticum, Ascophyllum nodosum, and Fucus spiralis), significantly inhibit Colletotrichum lagenarium growth, a pathogenic fungus with a broad host range. By changing the solvent extraction, it was noted that the amount of extracted secondary metabolites varies, due to the different polarities, varying thus also the antifungal activity. For instance, methanol extract from Cinnamomum cassia inhibits Fusarium moniliforme and Phyllosticta caricae growth. While $C$. cassia acetone extract inhibits $B$. cinerea and Glomerella cingulata growth. Hot water extract from $C$. cassia significantly inhibits $A$. niger, $B$. cinerea, $F$. moniliforme and P.caricae growth; and, Curcuma longa acetone extract inhibits $P$. caricae growth [8].

At the same time, both water and ethanolic extracts from garlic (Allium sativum), used for culinary purposes for decades present a series of bibliographic records regarding their antifungal properties. For instance, reported plant extracts from the Allium genus such as A. ampeloprasum (elephant garlic), A. ramosum (fragrant-flowered garlic), and A. sativum (culinary garlic); as well as plant extracts from the Capsicum genus such as $C$. annuum (jalapeño pepper), $C$. chinense (habanero pepper) and $C$. frutescens (tabasco pepper), showed, in vitro, a high antifungal activity against $B$. cinerea phytopathogenic fungus, ultimately inhibiting the spore germination. Thus concluding, that extracts from these plants could be suitable as a natural alternative to chemical fungicides [16]. Moreover, aqueous extracts from culinary garlic (A. sativum), onion (A. cepa), bakeri garlic (A. bakeri), fragrant garlic (A. odorum), oriental garlic (A. tuberosum) and bunching onion ( $A$. fistulosum) revealed to have antifungal activity against $A$. niger, and $A$. flavus (fungi causing infection in corn and peanuts), as well as against Aspergillus fumigatus growth, responsible for the deterioration of many foods [34]. In the same line, culinary garlic (A. sativum) and persian cumin (Carum carvi) extracts in cold distilled water, showed a resilient antifungal activity in vitro by inhibiting tomato pathogenic fungi growth: Fusarium oxysporum f. sp. lycopersici, B. cinerea and Rhizoctonia solani [35]. Additionally, garlic aqueous and ethanolic extract (in vitro) also works as an antifungal, by completely inhibiting mycelial growth and germination of fungal spores pre and post-harvest of Alternaria brassicicola, B. cinerea, Magnaporthe grisea, Neofabraea alba, P. expansum and Plectosphaerella cucumerina fungi $[10,36]$.

Another approach for the deployment of plant extracts is the use of essential oils as antifungals against phytopathogenic fungi, since these oils, usually come from aromatic plants with medicinal characteristics $[16,37,38]$.

\section{Essential oils}

Essential oils are substances with highly volatile components, synthesized and stored in glandular trichomes of aromatic plants, which can inhibit microbial growth $[10,13,15,39]$. As an example, basil oil (Ocimum basilicum), in vivo, acts as a post-harvest control of crown rot and anthracnose in banana (Musa acuminata), generated by Colletotrichum musae, Lasiodiplodia theobromae, and Fusarium proliferatum fungi. This control allows the fruits to be stored at low temperature $\left(13.5 \pm 1{ }^{\circ} \mathrm{C}\right)$ for 21 days, without causing damage or affecting their organoleptic properties [39]. Besides, Lemongrass oil (Cymbopogon citratus) at $500 \mathrm{ppm}$, completely inhibits sporulation and germinal tube generation of Colletotrichum coccodes, B. cinerea, Rhizopus stolonifer and Cladosporium herbarum fungus, which can cause diseases in tomato plantations. Therefore, lemongrass oil could work as a natural fungicide for the product when stored, limiting the pathogen spreading by reducing spores in the atmosphere and storage surfaces [13].

Mulan magnolia (Magnolia liliiflora) oil, has revealed to have a promising antifungal activity (in vitro) against Botrytis cinerea, Fusarium oxysporum, Fusarium solani, R. solani, Colletotrichum capsici, Phytophthora capsici, and Sclerotinia sclerotiorum spore germination, inhibiting all the analyzed pathogens. This oil also showed a potent antifungal effect against Phytophthora capsici, a pathogen causing the greenhouse-grown peppers rot. The results of this study indicated that mulan magnolia oil could be used as a natural alternative to synthetic fungicides [3]. Conversely, the Calocedrus macrolepis var. formosana oil, from a coniferous tree of China, presented $65 \%$ of antifungal activity, in vitro, against Pestalotiopsis funérea (a garden center pathogen), and $52.1 \%$ against Fusarium solani (potato pathogen) [4]. Suggesting thus, that the Calocedrus macrolepis var. formosana oil, could be used as a natural antifungal on potato cultures in greenhouses.

Essential oils effects on the $B$. cinerea has also been widely described. This pathogen, also called "gray mold", causes damages on fruits and vegetables harvest during storage and distribution. Essential oils have shown to inhibit, in vitro, the mycelial growth, spore germination and germ tube elongation in $B$. cinerea. Some of these oils are oregano (Origanum vulgare, and Origanum compactum), as well as syrian oregano (Origanum syriacum); dittany of Crete (Origanum dictamnus); sweet marjoram (Origanum majorana); mediterranean wild thyme (Thymus capitatus); thyme (Thyme glandulosus, and Thymus zygis); 
palmarosa (Cymbopogon martini); lavender (Lavandula stoechas); rosemary (Rosmarinus officinalis); wormseed (Dysphania ambrosioides); lemon eucalyptus (Corymbia citriodora); holy rope (Eupatorium cannabinum); henna tree (Lawsonia inermis); basil lime (Ocimum canum); clove basil (Ocimum gratissimum); holy basil (Ocimum sanctum); cinnamon (Cinnamomum zeylanicum); clove (Eugenia caryophyllata); lemon (Citrus limonum); peach (Prunus persica); ginger cassumunar (Zingiber cassumunar), and ginger (Zingiber officinale) $[14,16,38,40,41,42]$. A few of them, such as $O$. vulgare, $T$. capitatus, $O$. dictamnus, and $O$. majorana, have antifungal activity against Fusarium sp. fungus, also called dry tuber rot, which causes damage in stored potatoes [14].

It has also been observed that syrian oregano (O. syriacum), in vivo under greenhouse conditions, showed higher protection in tomato plants susceptible to gray mold disease, especially as a curative treatment [41]. Another essential oil with ascribed properties to prevent and treat plants against $B$. cinerea, is the ginger (Zingiber officinale) on grapes (Vitis spp.) storage [38]. In addition, essential oil of two clonal types of thyme, Thymus vulgaris (Laval-1 and Laval2 ), besides exhibiting antifungal activity against $B$. cinerea, also inhibits the Rhizopus stolonifer growth, a common pathogen in strawberries (Fragaria ananassa) storage [37]. Based on the above, essential oils could be considered as a potential source of sustainable fungicides for the treatment of fruits and vegetables against post-harvest pathogens.

We can, therefore, indicate that essential oils from plants can treat pathogenic fungi in fruits and vegetables post-harvest storage stage. However, further studies are needed to determine the identity of the bioactive compounds responsible for the mentioned antifungal activity. Despite this, bioactive compounds (derived from plants) exhibiting antifungal activity can still be considered as a fungicide alternative [21].

\section{Active compounds obtained from plants}

Extracts and essential oils contain secondary compounds metabolized by plants. These compounds are toxic and stored in the plant cells vacuoles. Among them are phenolic, steroid and terpenoid compounds. Their concentration depends on the environmental conditions and the pathogens incidence, which gives them their biopesticidal characteristic, targeting specifically against insect pests and pathogens. Furthermore, they are biodegradable, which means they can be used without causing severe damage to the environment $[10,15,19,24]$.

Then, it is very interesting to identify the active compound within extracts or oils, which can produce the intended effect. In literature, there are several examples, for instance, thymol (principal component), and carvacrol (monoterpenoid phenol which produces odor); characteristics of oregano oil (Origanum vulgare) (Figure 1). These compounds have antifungal activity against $B$. cinerea and Fusarium spp. fungus (fruits and vegetable pathogens), indicating that these compounds could be used individually as fungicides against these phytopathogenic fungi [14]. Besides, T-muurolol and $\alpha$-cadinol compounds (Figure 1) from the Calocedrus macrolepis var. formosan oil, exhibit antifungal activity against Rhizoctonia solani and $F$. oxysporum. Moreover, these compounds inhibit the mycelial growth of Fusarium solani, Pestalotiopsis funerea, Colletotrichum gloeosporioides and Ganoderma australe. Therefore, these two compounds (T-muurolol and $\alpha$-cadinol) could also be used as a natural control against a broad spectrum of plant pathogenic fungi [4].
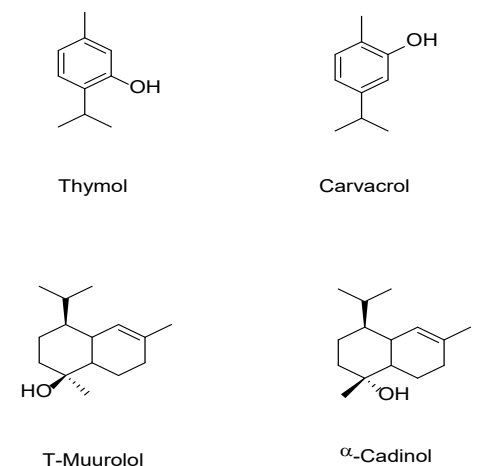

Figure 1. Main compounds structure (chemotypes) of $O$. vulgare essential oil (A) [43]. Chemical structures of the main compounds of C. macrolepis var. formosan essential oil (B) [4].
On the other hand, the rhizome methanolic extract of Acorus gramineus (Japanese rush), contains several compounds such as $\alpha$-asarone, caryophyllene, isoasarone, methyl isoeugenol and safrole (Figure 2). In vivo, It was possible to observe that the asaronaldehyde (2,4,5-trimethoxybenzaldehyde) active compound (Figure 2), showed $100 \%$ antifungal activity against Phytophthora infestans (tomatoes and potatoes pathogen) and $75 \%$ against $R$. solani (rice pest). While the $\alpha$-asarone compound showed $85 \%$ antifungal activity against $P$. infestans and $53 \%$ against $R$. solani; suggesting then, that these (potentially safer) compounds could be used as phytopathogen control agents [44]. In addition, lipid compounds ( $L P-B 1$ and $L P-B 2)$, isolated from the ethanol extract of Zimu leaf, showed maximum inhibition of Mycosphaerella eumusae mycelial growth, a banana pathogen [19].

Another compound is the oleoresin capsaicin (8-methyl-vanillyl-6nonenamide) (Figure 3), a spicy component of red pepper species, which works as antifungal against $B$. cinerea [45]. Consequently, these compounds could be well integrated with the biological control of plants diseases.<smiles>C/C=C/c1cc(OC)c(OC)cc1OC</smiles><smiles>C=CCc1cc(OC)c(OC)cc1OC</smiles><smiles>C=C1CC/C=C(\C)CC[C@@H]2[C@@H]1CC2(C)C</smiles>

$\alpha_{\text {-asarone }}$ isoasarone caryophyllene<smiles>C/C=C/c1ccc(OC)c(OC)c1</smiles><smiles>C=CCc1ccc2c(c1)COC2</smiles><smiles>COc1cc(OC)c(OC)cc1C=O</smiles>

methyl isoeugenol safrole asaronaldehyde

Figure 2. Chemical structures of the main compounds from the rhizome methanolic extract of $A$. gramineus [44].<smiles>COc1cc(CNC(=O)CCCC/C=C/C(C)C)ccc1O</smiles>

Figure 3. Chemical structures of capsaicin [45].

Garlic contains a significant number of sulfurous compounds (Figure 4), which exhibit potent antifungal properties $[10,31]$. These compounds include: 1) allicin (diallyl-dithiosulfinate), which has antifungal activity against Magnaporthe oryzae (rice pathogen), Hyaloperonospora parasitica (affects leaves and causes stalk necrosis) and Phytophthora infestans, which inhibits spores' germination and hyphae growth $[15,25,46,47,48]$. 2) ajoene $[(E, Z)$ 4,5,9-trithiadodeca-1,6,11-triene-9-oxide], which inhibits $A$. niger growth (fungus which produces aflatoxin-hepatocarcinogen pathogen in plants) through the phosphatidylcholine (PC) synthesis suppression (acting on the cell wall, in the cytosolic membrane), blocking then fungus morphogenic transformation. It also inhibits the spores' germination and conidia of Alternaria solani, Alternaria tenuissima, Alternaria triticina, Alternaria sp., Colletotrichum sp., Curvularia sp., Fusarium lini, Fusarium oxysporum, Fusarium semitectum, and Fusarium udum, plant pathogens [46, 47, 49, 50, 51]. 3) diallyl sulfide (DAS), diallyl disulphide (DADS) and allyl methyl disulfide, which completely inhibit Colletotrichum lindemuthianum growth, a banana pathogenic fungus causing anthracnose or dark spot disease [52]. 4) allivin, active against B. cinerea (gray rot) and Mycosphaerella arachidicola (early leaf spot) phytopathogenic fungi, associated with necrotic lesions generation, and Physalospora piricola, black rot in many fruit species and forest trees [53] 


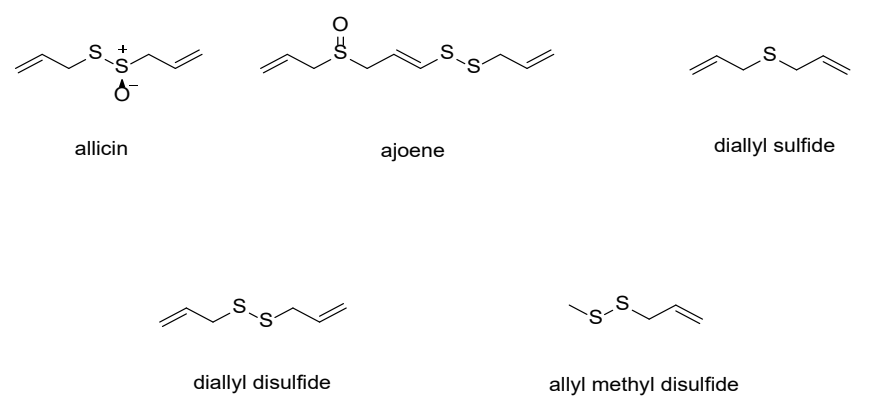

Figure 4. Chemical structures of the main compounds from garlic ( $A$. sativum) and onion (A. cepa) [54].

As mentioned above, these active compounds may also be referred to as preformed compounds, which have been isolated from crude extracts or essential oils from leaves and stems of plants $[10,15,19,24]$. They can be also classified into:

Phenolic compounds: Substances with an aromatic ring containing one or more hydroxyls which may also include functional derivatives. Some of the essential compounds include esters, alkyl parabens, and phenolic antioxidants. Simple phenolic compounds include monophenols, diphenols, and triphenols, such as flavones, flavonoid glycosides, coumarins, and anthraquinones. The action mechanism of simple phenols focuses on altering the cytoplasmic membrane and causing cell lysis; besides, they can also directly inhibit cellular proteins. These mechanisms are the ones allowing the microorganisms inhibition $[15,55]$. For instance, a high number of polyphenols extracted from Rhus muelleri leaves inhibit the growth of Fusarium oxysporum fungus, which causes destructive diseases in tomatoes, bananas, among other plant species [18]. Likewise, from the leaves and stem of Aquilegia vulgaris, the flavonoid 4'methoxy-5,7-dihydroxyflavone 6-C-glucoside (isocytisoside) was isolated (Figure 5), and presented antifungal activity against mold $A$. niger [55]. While flavonoid 5,7-dihydroxy-3,8-dimethoxyflavone (Figure 5), extracted from Pseudognaphalium robustum plant, reduced mycelial growth and partially affected conidial germination of Botrytis cinerea fungus, by decreasing oxygen consumption in conidial germination and disrupting the integrity of the plasma membrane [56]. Based on the above, these polyphenols and flavonoids extracted from plants are also an alternative to be used as biological fungicides.

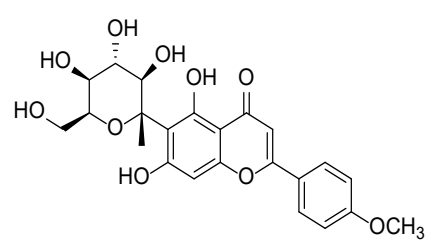

isocytisoside

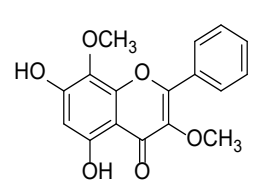

5,7-dihydroxi-3,8-dimethoxyflavone
Figure 5. Chemical structures of flavonoids isolated from leaves and stem of A. vulgaris (A), and flavonoids isolated from P. robustum extracts (B) [55, 56].

Terpenoids compounds: Substances stored in the trichomes or glandular hairs (specialized structures of the outer plant layers). Essential oils, in general, have a high concentration of terpenes and sesquiterpenes [15, 55]. For instance, carrot oil (Dacus carota), contains four esters of sesquiterpenes such as carotol (Figure 6); and has antifungal activity, inhibiting $65 \%$ of the Alternaria alternata growth, a phytotoxic fungus of carrot plants. In addition, sesquiterpene, isolated from dichloromethane extracts of Vernonanthura tweedieana roots, records antifungal activity against Trichophyton mentagrophytes [55]. In Chile, canelo (Drimys winteri) essential oil, contains different amounts of unknown polygodial and drimenol (Figure 7) [57]. These terpenes have antifungal properties against Gaeumannomyces graminis fungus, a causal agent of infection in wheat [58]. Furthermore, polygodial and drimenol terpenes isolated from canelo have shown to have antifungal activity against Botrytis cinerea, the causal agent of infection in table grape $[59,60]$.

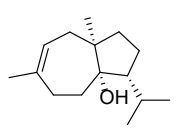

Carotol

Figure 6. Chemical structure of sesquiterpene isolated from carrot oil ( $D$. carota) [55].<smiles>CC1CCCC2(C)C(C=O)C(C=O)=CCC12</smiles>

Polygodial<smiles>CC1=CCC2C(C)(C)CCC[C@]2(C)[C@H]1CO</smiles>

Drimenol
Figure 7. Chemical structures of canelo (D. winteri) essential oil [59].

Diterpenoids 1) 7 $\alpha$-hydroxy-8(17)-labden-15-oic acid (salvic acid), and 2) $7 \alpha$-acetanoyloxy-8(17)-labden-15-oic acid (acetylsalvic acid); hemisynthetic

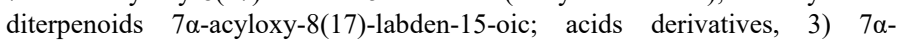
propanoyloxy-8(17)-labden-15-oic acid (propanoylsalvic acid), and 4) $7 \alpha$ butanoyloxy-8(17)-labden-15-oic acid (butanoylsalvic acid) (Figure 8), isolated from the resinous exudate Eupatorium salvia leaves (salvia macho), in vitro, inhibit the mycelial growth of $B$. cinerea [61]. At the same way (in vitro), diterpenoids sclareol and 13-epi-sclareol (Figure 9), isolated and purified from the resinous exudate of Pseudognaphalium cheiranthifolium, can also inhibit $B$. cinerea mycelial growth [62]. Deducing that these diterpenes could be used as a natural control against the phytopathogenic fungus $B$. cinerea.

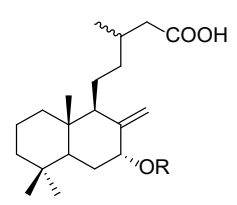

Salvic acid $(\mathrm{R}=\mathrm{H})$

Acetylsalvic acid $\left(\mathrm{R}=\mathrm{COCH}_{3}\right)$

Propanoylsalvic acid $\left(\mathrm{R}=\mathrm{COCH}_{2} \mathrm{CH}_{3}\right)$

Butanoylsalvic acid $\left(\mathrm{R}=\mathrm{COCH}_{2} \mathrm{CH}_{2} \mathrm{CH}_{3}\right)$

Isopentanoylsalvic acid $\left(\mathrm{R}=\mathrm{COCH} 2 \mathrm{CH}\left(\mathrm{CH}_{3}\right)_{2}\right)$

Figure 8. Chemical structures of diterpenoids isolated from the resinous exudate of E. salvia leaves [61].<smiles>C=C[C@H](O)CCC1C(C)(O)CCC2C(C)CCCC21C</smiles>

Sclareol<smiles>C=CC(C)(O)CCCC1C(C)(O)CCC2C(C)(C)CCCC21C</smiles>

13-epi-Sclareol
Figure 9. Chemical structures of diterpenoids isolated from the resinous exudate of $P$. cheiranthifolium [62].

Triterpenes and sesquiterpene lactones isolated from Schinus molle's (Peruvian peppertree) leaves and fruits have antifungal activity against plant pathogenic fungi such as $A$. niger, A. flavus, Alternaria alternata, Microsporum griseum, Penicillium cyclopium and Penicillium italicum, suggesting that these compounds could be a natural fungicide against a wide range of plant pathogenic fungi [32]. Likewise, triterpenes, pristimerin and celastrol (Figure 10), isolated in vitro from Celastrus hypoleucus root, exhibited an inhibitory effect on mycelial growth of $R$. solani and Glomerelia cinguiata (Antracnosis) phytopathogenic fungi. In vivo, pristimerin showed a $97 \%$ preventive, and a $67 \%$ curative impact against Blumeria graminis (wheat mold); and celastrol registered an $81 \%$ preventive, and a $46 \%$ curative impact against the same fungus pathogen [55]. 


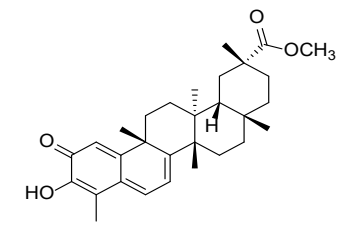

Pristimerin

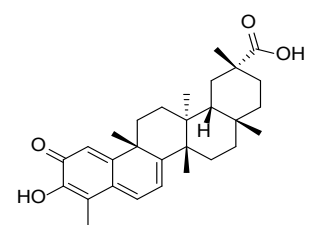

Celastrol
Figure 10. Chemical structures of triterpenes isolated from C. hypoleucus $\operatorname{root}[55]$.

Saponins compounds: Glycosylated compounds stored in plant cells, which regulate growth and protect the plant from the attack of pathogens and insects. They are divided into triterpenes, steroids, and steroidal glycoalkaloids. Triterpenoid saponins are mainly found in dicotyledonous plants, but can also be found in some monocotyledonous plants. While steroid saponins are mostly found in monocotyledonous [55, 63, 64].

For instance, triterpene saponin CAY-1, extracted from cayenne pepper (Capsicum frutescens), recorded antifungal activity in vitro against Candida spp. and Aspergillus fumigatus [55]. Other triterpenic saponins, with significant antifungal in vitro activity, were two saponins from Diploknema butyracea mixture, identified as 3-O[ $\beta$-D-glucopyarnosyl- $\beta$-D-glucopyranosyl] -16- $\alpha$ hydroxyprotobassic acid-28-O [arabinopyranosyl- glucopyranosylxylopyranosyl]- arabino pyranoside (MI-I), and 3-O- $\beta$-D-glucopyranosyl glucopyranosyl- glucopyranosyl-16- $\alpha$-hydroxyprotobassic acid-28-O[arabinopyranosyl-xylopyranosyl-arabinopyrnosyl]- apiofuranoside (MI-III). Besides, a single saponin extracted from Sapindus mukorossi which was identified as 3-O-[O-acetyl- $\beta$-D-xylopyranosyl- $\beta$-D-arabinopyranosyl- $\beta$-Drhamnopyranosyl] hederagenin-28-O-[ $\beta$-D-glucopyranosyl- $\beta$-Dglucopyranosyl- $\beta$-D- rhamnopyranosyl] ester (SM-1) (Figure 11), can inhibit Rhizoctonia bataticola and Sclerotium rolfsii growth [64]. While the Balanites aegyptiaca fruit extract, rich in saponins, presents (in vitro) a high inhibition $(81 \%)$ against Pythium ultimum, and Alternaria solani fungi growth. Suggesting that saponins may then play an important role in the control of phytopathogenic fungi [65].

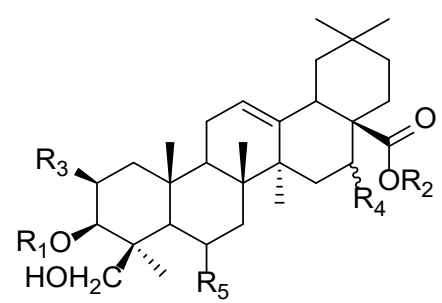

\begin{tabular}{|c|c|c|c|c|c|}
\hline Compound & R1 & R2 & R3 & OH & R5 \\
\hline MI-I & Glu-Glu & Ara-Xyl-Ara & OH & OH & OH \\
\hline MI-III & Glu-Glu-Glu & Ara-Xyl-Ara-Api & OH & H & OH \\
\hline SM-I & $\begin{array}{c}\text { Xyl(OAc)- } \\
\text { Ara-Rha }\end{array}$ & Glu-Glu-Rha & H & OH & H \\
\hline $\begin{array}{c}18- \\
\text { hydroxiproto- } \\
\text { bassic acid }\end{array}$ & H & H & OH & H & OH \\
\hline $\begin{array}{c}\text { Hederagenin } \\
\text { Sedere }\end{array}$ & H & H & H & OH & H \\
\hline
\end{tabular}
[64].

Figure 11. Chemical structures of D. butyracea, and S. mukorossi saponins

Alkaloids compounds: Compounds with nitrogen in their ring. Indole alkaloids, pyridine alkaloids, benzylisoquinoline, and alkaloids are classified according to the simple heterocyclic ring in their structure. Some alkaloids have been reported to alter biological functions and exhibit antimicrobial functions $[66,67]$.
For instance, the allosecurinine (Figure 12), isolated from the Phyllanthus amarus root, in vitro, completely inhibits the spore germination of Curvularia sp., Curvularia lunata, Collectotrichum sp., Colletotrichum musae and Heterosporium sp. phytopathogenic fungi [67]. Also, the dyhydropyrrole [2(3,4-dimethyl-2,5-dihydro-1H-pyrrol-2-yl)-1'-methylethyl pentanoate] (Figure 13), isolated from Datura metel plant (devil's trumpet), presents activity against A. niger, A. flavus, and Aspergillus fumigatus, molds infecting a wide range of foods [55]. Likewise, the alkaloid 1-methyl-2-[6'-(3', ,4', methylenedioxyphenyl) hexyl]-4-quinolone (Figure 14), isolated from the ethyl acetate extract of Ruta graveolens leaves; registers, in vitro, high antifungal activity against Botrytis cinerea, Colletotrichum gloeosporioides, Colletotrichum acutatum, Colletotrichum fragariae, Phomopsis obscurans and Phomopsis vitícola phytopathogenic fungi. Based on this, it can be inferred that alkaloids present in plants could potentially be used as fungicides of plant pathogens [67].<smiles>O=C1C=C2C=C[C@H]3C[C@H]2[C@H]2CCCCN2C3C1</smiles>

Figure 12. Chemical structures of allosecurinine isolated from P. amarus $\operatorname{root}[66]$.<smiles>CCCCC(=O)OC(C)CC1NCC(C)=C1C</smiles>

Figure 13. Chemical structures of dyhydropyrrole alkaloid isolated from the D. metel plant [55].<smiles>Cn1c(CCCCCCc2ccc3c(c2)OCO3)cc(=O)c2ccccc21</smiles>

Figure 14. Chemical structures of alkaloid isolated from $R$. graveolens leaves [68].

\section{CONCLUSIONS}

In this review, we observe that natural compounds derived from plants are worthwhile to treat fungal infections; phytopathogens, which nowadays remain as one of the most common plant diseases, and also represent one of the most significant issues for agricultural companies.

We could also observe that extracts, essential oils, and active compounds from plants have efficient antifungal agents, which are potent and less toxic against phytopathogenic fungus, rather than synthetic fungicides. Likewise, they could partially or entirely replace the use of chemical antifungals, which increase resistance in fungi and pollute the environment, generating an eco-friendly control mechanism as well as lowering costs for agricultural companies.

Finally, it was possible to observed that the compounds with the highest and best antifungal activity were the ones from plants which proved to be active against phytopathogenic fungi, considering these products useful in crops and avoiding any chemical fungicide implementations.

\section{ACKNOWLEDGMENTS}

We want to thanks to Project Fondecyt 11140194. Project Fondecyt 1170706. 


\section{REFERENCES}

1. Silva-Moreno E, Brito-Echeverría J, López M, Ríos J, Balic I, CamposVargas R, Polaco R. (2016). Effect of cuticular waxes compounds from table grapes on growth, germination and gene expression in Botrytis cinerea. World J Microbiol Biotechnol, 32: 68-74.

2. Talibi I, Askarne L, Boubaker H, Boudyach EH, Msanda F, Saadi B, Aoumar AAB. (2012). Antifungal activity of some Moroccan plants against Geotrichum candidum, the causal agent of postharvest citrus sour rot. Crop protection, 35: 41-46.

3. Bajpai VK, Kang SC. (2012). In Vitro and In Vivo inhibition of plant pathogenic fungi by essential oil and extracts of Magnolia liliflora. Desr $J$ Agr Sci Tech, 14: 845-856.

4. Chang HT, Cheng YH, Wu CL, Chang ST, Chang TT, Su YC. (2008). Antifungal activity of essential oil and its constituents from Calocedrus macrolepis var. formosana, florin leaf against plant pathogenic fungi. Bioresource Technol, 99: 6266-6270.

5. Hof H. (2001). Guest Commentary: Critical Annotations to the use of azole antifungals for plant protection. Antimicrob Agents Chemother, 45(11): 2987-2990.

6. Korres AMN, Buss DS, Ventura JA, Fernandes PMB. (2011). Candida krusei and Kloeckera apis inhibit the causal agent of pineapple fusariosis, Fusarium guttiforme. Fungal Biology, 115: 1251-1258.

7. Díaz-Dellavalle P, Cabrera A, Alem D, Larrañaga P, Ferreira F, Dalla M. (2011). Research: Antifungal activity of medicinal plant extracts against phytopathogenic fungus Alternaria spp. Chil J Agr Res, 71(2): 231-239.

8. Lee SH, Chang KS, Su MS, Huang YS, Jang HD. (2007a). Effects of some Chinese medicinal plant extracts on five different fungi. Food Control, 18: 1547-1554.

9. Satish S, Mohana DC, Ranhavendra MP, Raveesha KA. (2007). Antifungal activity of some plant extracts against important seed borne pathogens of Aspergillus sp. J Agr Sci Tech, 3(1): 109-119.

10. Daniel CK, Lennox CL, Vries FA. (2015). In-vitro effects of garlic extracts on pathogenic fungi Botrytis cinerea, Penicillium expansum and Neofabraea alba. S Afr J Sci, 111(7/8): 1-8.

11. Thompson L. (2002). Antifúngicos. Rev Chil Infectol, 19(1): 22-25. https://dx.doi.org/1 0.4067/S071610182002019100003.

12. Trösken ER, Scholz K, Lutz RW, Völkel W, Zarn JA, Lutz WK. (2004). Comparative assessment of the inhibition of recombinant human CYP19 (Aromatase) by azoles used in agriculture and as drugs for humans. Endocr Res, 30(3): 387-394.

13. Tzortzakis NG, Economakis CD. (2007). Antifungal activity of lemongrass (Cympopogon citratus L.) essential oil against key postharvest pathogens. Innov Food Sci Emerg Technol, 8(2): 253-258.

14. Daferera DJ, Ziogas BN, Polissiou MG. (2003). The effectiveness of plant essential oils on the growth of Botrytis cinerea, Fusarium sp. and Clavibacter michiganensis subsp. michiganensis. Crop Protection, 22: 3944.

15. Martínez JA. Natural fungicides obtained from plants. (2012). Chapter 1. In: Dhanasekaran D, Thajuddin N, Panneerselvam A (Eds). Fungicides for plant and animal diseases. Europe: InTech, 3-28.

16. Wilson CL, Solar JM, El Ghaouth A, Wisniewski ME. (1997). Rapid evaluation of plant extracts and essential oils for antifungal activity against Botrytis cinerea. Plant Dis, 81(2): 204-210.

17. Aala F, Kalsom U, Khodavandi A, Jamal, F. (2010). In vitro antifungal activity of allicin alone and in combination with two medications against six dermatophytic fungi. Afr J Microbiol Res, 4(5): 380-385.

18. Jasso de Rodríguez D, Trejo-González FA, Rodríguez-García R, DíazJimenez MLV, Sáenz-Galindo A, Hernández-Castillo FD, VillarrealQuintanilla JA, Peña-Ramos FM. (2015). Antifungal activity in vitro of Rhus muelleri against Fusarium oxysporum f. sp. lycopersici. Ind Crop Prod, $\mathbf{7 5}$ : 150-158.

19. Thangavelu R, Ganga P, Gopi M, Mustaffa MM. (2013). Management of eumusae leaf spot disease of banana caused by Mycosphaerella eumusae with Zimmu (Allium sativum $\mathrm{x}$ Allium cepa) leaf extract. Crop protection, 46: 100-105.

20. Cavieres MF. Exposición a pesticidas y toxicidad reproductiva y del desarrollo en humanos. (2004). Análisis de la evidencia epidemiológica y experimental. Rev Med Chile, 132: 873-879.

21. Díaz P, Cabrera A, Alem D, Larrañaga P, Ferreira F, Dalla M. (2011). Antifungal activity of medicinal plant extracts against phytopathogenic fungus Alternaria spp. Chilean JAR, 71(2): 231-239.

22. Sayago JE, Ordoñez RM, Negrillo L, Torres S, Isla MI. (2012). Antifungal activity of extracts of extremophile plants from the Argentine Puna to control citrus postharvest pathogens and Green mold. Postharvest Biol Technol, 67: 19-24.

23. Fieira C, Oliveira F, Calegari RP, Machado A, Coelho AR. (2013). In vitro and in vivo antifungal activity of natural inhibitors against Penicillium expansum. Ciênc Tecnol Aliment, 33(1): 40-46.

24. Sales MDC, Costa HB, Bueno PM, Ventura JA, Meira DD. (2016). Antifungal activity of plant extracts with potential to control plant pathogens in pineapple. Asian Pac J Trop Biomed, 6(1): 26-31.

25. Slusarenko AJ, Patel A, Portz D. (2008). Control of plant diseases by natural products: Allicin from garlic as a case study. Eur J Plant Pathol, 121: 313322 .

26. Petatán-Sagahón I, Anducho-Reyes MA, Silva-Rojas HV, Arana-Cuenca A, Tellez-Jurado A, Cárdenas-Álvarez IO, Mercado-Flores Y. (2011). Isolation of bacteria with antifungal activity against the phytopathogenic fungi Stenocarpella maydis and Stenocarpella macrospora. Int J Mol Sci, 12: 5522-5537.

27. Bennett RN, Wallsgrove RM. (1994). Transley Review No. 72. Secondary metabolites in plant defense mechanisms. New Phytol, 127: 617-633.

28. Dahham SS, Ali MN, Tabassum H, Khan M. (2010). Studies on antibacterial and antifungal activity of pomegranate (Punica granatum L.). Am-Euras $J$ Agric \& Environ Sci, 9 (3): 273-281.

29. Pundir RK, Jain P, Sharma C. (2010). Antimicrobial activity of ethanolic extracts of Syzygium aromaticum and Allium sativum against food associated bacteria and fungi. Ethnobot leaflets, 14: 344-360.

30. Okigbo RN, Ogbonnaya UO. (2006). Antifungal effects of two tropical plant leaf extracts (Ocimum gratissimum and Afromomum melegueta) on postharvest yam (Dioscorea spp.) rot. Afr J Biotechnol, 5(9): 727-731.

31. Ikegbunam M, Ukamaka M, Emmanuel O. (2016). Evaluation of the antifungal activity of aqueous and alcoholic extracts of six species. Am J Plant Sci, 7: 118-125.

32. Quiroga EN, Sampietro AR, Vattuone MA. (2001). Short Communication: Screening antifungal activities of selected medicinal plants. $J$ Ethnopharmacol, 74: 89-96.

33. Fernandes-Peres JC, Retz-De Carvalho L, Gonçalez E, Saggion-Berian LO, D'arc Felicio J. (2012). Evaluation of antifungal activity of seaweed extracts. Cienc agrotec, 36(3): 294-299.

34. Yin M, Tsao S. (1999). Inhibitory effect of seven Allium plants upon three Aspergillus species. Int J Food Microbiol, 49: 49-56.

35. Alkhail AAA. (2005). Antifungal activity of some extracts against some plant pathogenic fungi. PakJ Bio Sci, 8(3): 413-417.

36. Curtis H, Noll U, Störmann J, Slusarenko AJ. (2004). Broad-spectrum activity of the volatile phytoanticipin allicin in extracts of garlic (Allium sativum L.) against plant pathogenic bacteria, fungi and Oomycetes. Physiol Mol Plant Pathol, 65: 79-89.

37. Bhaskara MV, Angers P, Gosselin A, Arul J. (1998). Characterization and use of essential oil from Thymus vulgaris against Botrytis cinerea and Rhizopus stolonifer in strawberry fruits. Phytochemistry, 47(8): 1515-1520.

38. Tripathi P, Dubey NK, Shukla AK. (2008). Use of some essential oils as post-harvest botanical fungicides in the management of grey mould of grapes caused by Botrytis cinerea. World J Microbiol Biotechnol, 24: 39-46.

39. Anthony S, Abeywickrama K, Wijeratnam, SW. The effect of spraying essential oils of Cymbopogon nardus, Cymbopogon flexuosus and Ocimum basilicum on postharvest diseases and storage life of Embul banana. (2003). J Horticult Sci Biotechnol, 78(6): 780-785. 
40. Bouchra C, Achouri M, Idrissi LM, Hmamouchi M. (2003). Chemical composition and antifungal activity of essential oils of seven Moroccan Labiatae against Botrytis cinereal Pers: Fr. J Ethnopharmacol, 89: 165-169.

41. Soylu EM, Kurt Ş, Soylu S. (2010). In vitro and in vivo antifungal activities of the essential oils of various plants against tomato grey mould disease agent Botrytis cinerea. Int J Food Microbiol, 143: 183-189.

42. Vitoratos A, Bilalis D, Karkanis A, Efthimiadou A. (2013). Antifungal activity of plant essential oils against Botrytis cinerea, Penicillium italicum and Penicillium digitatum. Not Bot Horti Agrobo, 41(1): 86-92.

43. Bouyahya A, Jamal A, Edaoudi F, Et-Touys A, Bakri Y, Dakka N. (2016). Origanum compactum Benth: A review on phytochemistry and pharmacological properties. Med Aromat Plants, 5: 4.

44. Lee SH. (2007c). Short Communication: Fungicidal property of active component derived from Acorus gramineus rhizome against phytopathogenic fungi. Bioresour Technol, 98: 1324-1328.

45. Xing F, Cheng G, Yi K. (2006). Study on the antimicrobial activities of the capsaicin microcapsules. J Appl Polym Sci, 102: 1318-1321.

46. Davis SR, Perrie R, Apitz-Castro R. (2003). The in vitro susceptibility of Scedosporium prolificans to ajoene, allitridium and a raw extract of garlic (Allium sativum). J Antimicrob Chemother, 51: 593-597.

47. Hughes BG, Lawson LD. (1991). Antimicrobial effects of Allium sativum L. (garlic), Allium ampeloprasum L. (elephant garlic), and Allium cepa L. (onion), garlic compounds and commercial garlic supplement products. Phytother Res, 5: 154-158.

48. Mikaili P, Maadirad S, Moloudizargari M, Aghajanshakeri S, Sarahroodi S. (2013). Therapeutic uses and pharmacological properties of garlic, shallot, and their biologically active compounnds. Iran J Basic Med Sci, 16: 10311048 .

49. Benkeblia N. (2004). Antimicrobial activity of essential oil extracts of various onions (Allium cepa) and garlic (Allium sativum). Lebensm Wiss UTechnol, 37: 263-268.

50. San-Blas G, Urbina JA, Marchán E, Contreras LM, Sorais F, San-Blas F. (1997). Inhibition of Paracoccidioides brasiliensis by ajoene is associated with blockade of phosphatidylcholine biosynthesis. Microbiology, 143: 1583-1586.

51. Singh UP, Pandey VN, Wagner KG, Singh KP. (1990). Antifungal activity of ajoene, a constituent of garlic (Allium sativum). Can J Bot, 68: 1354-1356.

52. Bianchi A, Zambonelli A, Zechini A, Bellesia F. (1997). Ultrastructural studies of the effects of Allium sativum on phytopathogenic fungi in vitro. Plant Dis, 81: 1241-1246.

53. Wang HX, Ng TB. (2001). Purification of allivin, a novel antifungal protein from bulbs of the round-cloved garlic. Life Sci, 70: 357-365.

54. Ali M, Thomson M, Afzal M. (2000). Review: Garlic and onions: their effect on eicosanoid metabolism and its clinical relevance. PLEFA, 62(2): 55-73.

55. Abad MJ, Ansuategui M, Bermejo P. (2007). Active antifungal substances from natural sources. ARKIVO, 8: 116-145.

56. Cotoras M, Mendoza L, Muñoz A, Yáñez K, Castro P, Aguirre M. (2011). Fungitoxicity against Botrytis cinerea of a flavonoid isolated from Pseudognaphalium robustum. Molecules, 16: 3885-3895.

57. Muñoz-Concha D, Vogel H, Yunes R, Razmilic I, Bresciani L, Malheiros A. (2007). Presence of polygodial and drimenol in Drimys populations from Chile. Biochem Syst Ecol, 35: 434-438.

58. Monsálvez M, Zapata N, Vargas M, Berti M, Bittner M, Hernández V. (2010). Antifungal effects of $n$-hexane extract and essential oil of Drimys winteri bark against Take-All disease. Ind Crops Prod, 31: 239-244.

59. Carrasco H, Robles-Kelly C, Rubio J, Olea AF, Martínez R, Silva-Moreno E. (2017). Antifungal effect of polygodial on Botrytis cinerea, a fungal pathogen affecting table grapes. Int J Mol Sci, 18: 2251.

60. Robles-Kelly C, Rubio J, Thomas M, Sedán C, Martinez R, Olea AF, Carrasco H, Taborga L, Silva-Moreno E. (2016). Effect of drimenol and synthetic derivatives on growth and germination of Botrytis cinerea: evaluation of possible mechanism of action. Pestic Biochem Physiol, 141: $50-56$.
61. Mendoza L, Espinoza P, Urzua A, Vivanco M, Cotoras M. (2009). In vitro antifungal activity of the diterpenoid $7 \alpha$-hydroxy-8(17)-labden-15-oic acid and its derivatives against Botrytis cinerea. Molecules, 14: 1966-1979.

62. Mendoza L, Sepúlveda C, Melo R, Cotoras M. (2015). Characterization of the antifungal activity against Botrytis cinerea of sclareol and 13-episclareol, two labdane-type diterpenoids. J Chil Chem Soc, 60(3): 3024-3028.

63. Mert-Türk F. (2006). Saponins versus plant fungal pathogens. J Cell Mol Biol, 5: 13-17.

64. Saha S, Walia S, Kumar J, Parmar BS. (2010). Structure-biological activity relationships in triterpenic saponins: the relative activity of protobassic acid and its derivatives against plant pathogeninc fungi. Pest Manag Sci, 66: 825831.

65. Chapagain BP, Wiesman Z, Tsror L. (2007). In vitro study of the antifungal activity of saponin-rich extracts against prevalent phytopathogenic fungi. Ind Crops Prod, 26: 109-115.

66. Facchini PJ. (2001) Alkaloid biosynthesis in plants: biochemistry, cell biology, molecular regulation, and metabolic engineering applications. Annu Rev Plant Physiol Plant Mol Biol, 52: 29-66.

67. Singh AK, Pandey MB, Singh UP. (2007). Antifungal activity of an alkaloid allosecurinine against some fungi. Mycobiology 35(2): 62-64.

68. Oliva A, Meepagala KM, Wedge DE, Harries D, Hale AL, Aliotta G, Duke SO. (2003). Natural fungicides from Ruta graveolens L. leaves, including a new quinolone alkaloid. J Agric Food Chem, 51: 890-896. 